\title{
Strategi Komunikasi Merek Melalui Pemasaran Berbasis Empati bagi Pelaku UMKM pada Masa Pandemi Covid-19 di Kota Bengkulu
}

\author{
Sapta Sari*, Indria \\ Fakultas Ilmu-Ilmu Sosial Prodi Ilmu Komunikasi, Universitas Dehasen Bengkulu, Indonesia \\ Coresponding Author: sapta.sari26@gmail.com
}

\begin{tabular}{ll}
\hline \hline Article history & Abstrak: Penelitian ini memberikan uraian bagaimana strategi \\
Dikirim: & komunikasi merek melalui pemasaran berbasis empati yang \\
12-01-2022 & dilakukan oleh pelaku UMKM di Kota Bengkulu. Pelaku UMKM \\
Direvisi: & yang dijadikan sebagai objek penelitian adalah pelaku UMKM \\
16-01-2022 & yang menggunakan Instagram sebagai media promosi di Kota \\
& Bengkulu. Uraian strategi komunikasi merek ini didapat dari \\
Diterima: & konsep komunikasi merek dan pemasaran berbasis empati, yaitu \\
17-01-2022 & Empathy Maps dari Dave Gray dengan pendekatan studi literatur \\
& yang dilakukan pada bulan Desember 2021. Strategi komunikasi \\
Key words: & merek melalui pemasaran berbasis empati yang dilakukan oleh \\
\hline Komunikasi Merek; & pelaku UMKM di Kota Bengkulu melalui dua segi, yaitu isi \\
Empathy Maps; & pesan dan media yang digunakan. Bisa disimpulkan bahwa, \\
Pemasaran Empati; & pelaku UMKM di Kota Bengkulu melakukan inovasi dalam \\
UMKM & promosi produknya melalui pesan yang menarik dan mengikat \\
& emosional pembeli melalui akun Instagram sebagai media yang \\
& dipilih untuk promosi. \\
\hline \hline
\end{tabular}

\section{PENDAHULUAN}

Pandemi Covid-19 membawa perubahan yang sangat berarti bagi geliat Usaha Mikro Kecil Menengah atau disingkat UMKM di Indonesia termasuk di Kota Bengkulu. Banyak pelaku usaha yang mengalami penurunan penjualan semenjak pandemi ini. Penurunan penjualan ini tentu imbas dari kebijakan pemerintah yang mengharuskan masarakat untuk tetap di rumah dan jaga jarak, yang mengakibatkan berkurangnya mobilitas masyarakat untuk membeli kebutuhannya di luar. Situasi demikian tentu saja tidak bisa dibiarkan begitu saja, sementara pendapatan harus tetap masuk ditambah masa pandemi yang tidak bisa diprediksi pasti kapan berakhirnya. Tentu saja, para pelaku usaha UMKM ini harus menjalankan sebuah strategi sebagai solusi untuk mendapatkan penghasilan di masa pandemi.

Usaha yang dijalankan oleh pelaku UMKM ini tentu saja sangat berkaitan erat dengan produk yang mereka jual. Produk tentu saja harus memiliki nilai jual atau setidaknya memiliki daya tarik sehingga pembeli tertarik untuk membelinya. Produk berhubungan dengan merek dagang, sebagaimana yang diungkapkan oleh para ahli yang menyatakan bahwa merek sangat penting artinya bagi pembeli karena lewat merek mereka bisa mengenali produk. Lebih jauh lagi, sebuah merek bisa melindungi produk dari kemiripan produk dengan ciri dan tampilan yang mirip (Aaker, 2012). Artinya, produk dengan merek yang mudah diingat menjadi cara atau trik dalam menarik perhatian konsumen untuk membeli.

Merek merupakan aset berharga yang dimiliki oleh sebuah perusahaan guna memberikan keuntungan, dengan demikian merek menjadi bagian yang sangat 
penting dalam sebuah pemasaran dan pengelolaan merek yang tepat bisa mendukung penjualan sebuah produk. Tujuan dasar dari pembangunan merek tersebut adalah untuk membangun kesadaran akan keberadaaan merek. Selain itu juga bisa membangun asosiasi merek dan menciptakan kesetiaan konsumen terhadap merek (Aaker, 2014).

Pandemi Covid-19 yang sudah berlangsung selama kurang lebih 2 tahun ini membuat masyarakat cenderung untuk lebih selektif dalam membeli produk, terutama produk makanan dan minuman. Selektif di sini dalam arti memilah produk makanan dan minuman mana yang layak untuk dikonsumsi sekaligus terjangkau harganya. Sementara kebijakan untuk di rumah saja membuat masyarakat kesulitan dalam memenuhi kebutuhan mereka sehari-hari termasuk dalam membeli makanan. Untuk itu para pelaku UMKM telah beralih dari melakukan penjualan secara offline menjadi penjualan secara online. Mereka cenderung memilih platform media sosial sebagai media berjualan selama pandemi Covid-19. Media sosial yang paling banyak digunakan oleh para pelaku UMKM di kota Bengkulu sebagai media berjualan mereka adalah Instagram.

Sejak awal kemunculannya karena sosial media telah menciptakan cara baru bagi individu merek maupun perusahaan untuk berkomunikasi berkolaborasi dan berbagi informasi dengan pihak lain yang memiliki kesamaan ketertarikan (Kusumasondjadja, 2018). Sebagai contoh sosial media semakin banyak digunakan oleh para pemasar sebagai alat komunikasi dengan konsumen melalui pembagian informasi produk berinteraksi dengan konsumen berdasarkan pertanyaan atau keluhan dan kegiatan pemasaran lainnya.

Dalam kondisi saat ini peralihan ke konten digital dilakukan dengan pendekatan personal dan fokus pada pesan yang menyatakan dukungan pada upaya pencegahan penyebaran virus Covid 19. Hal tersebut dapat membangun keterikatan dengan konsumen yang pada akhirnya dapat mempengaruhi persepsi khalayak mengenai merek tersebut (Hoekstra \& Leeflang, 2020). Menunjukkan empati untuk situasi yang dialami konsumen saat ini dan peran lingkungan yang lebih luas lagi akan membangun itikad baik dari konsumen. Melakukan analisa bagaimana perjalanan konsumen dalam pembelian produk dan menemukan cara agar konsumen dapat terhindar dari kontak langsung dapat mengurangi rasa khawatir akan resiko penularan dan mendorong terjadi pembelian produk lebih besar (Steimer, 2020).

Media sosial yang digunakan para pelaku UMKM di kota Bengkulu untuk memasarkan produk produk adalah melalui Instagram. Mereka memilih Instagram karena karena media sosial ini menyediakan fasilitas yang cukup memadai dibanding dengan media sosial lainnya terutama dalam hal penampilan. Instagram yang menonjolkan gambar atau foto dimanfaatkan oleh pelaku UMKM di kota Bengkulu tidak hanya sebagai lapak untuk mereka berjualan tetapi juga dijadikan sebagai sarana untuk promosi produk yang mereka jual kepada konsumen selama pandemi Covid-19.

Berdasarkan dari uraian diatas studi ini akan mengkaji bagaimana implementasi dari strategi komunikasi merek melalui pemasaran empati oleh pelaku UMKM di Kota Bengkulu selama pandemi Covid-19 melalui media sosial Instagram. Berdasarkan dari tinjauan konsep yang di dijadikan sebagai kajian dalam studi ini strategi komunikasi Maret melalui pemasaran empat ini dilakukan meliputi isi pesan dan penggunaan media yang dipilih dalam melakukan promosi dan 
mempertahankan reputasi merek sebuah produk sekaligus membangun keterikatan dengan konsumennya. Studi ini bisa menjadi studi awal dalam melakukan kajian pada dampak komunikasi merek yang dilakukan terhadap perilaku konsumen sebagai dasar pengambilan keputusan dalam melakukan perencanaan strategi bauran pemasaran serta sebagai kajian literatur yang dapat menjadi referensi bagi pelaku UMKM di kota Bengkulu khususnya dan di Indonesia pada umumnya mengenai bagaimana strategi komunikasi merek melalui pemasaran berbasis empati dilakukan selama pandemi Covid-19.

\section{KAJIAN TEORI}

\section{Komunikasi Merek}

Komunikasi merek merupakan penghubung antara konsumen dengan perusahaan dan konsumen bisa mengembangkan kepercayaan dan loyalitas terhadap merek (Kotler \& Keller, 2012). Sebagai bagian dari pengelolaan sebuah merek komunikasi merek memegang peranan penting supaya perusahaan bisa bertahan dan berkembang. Komunikasi merek merupakan proses penyampaian pesan dari perusahaan kepada konsumen melalui penggunaan media tertentu yang menghasilkan evaluasi keseluruhan dari konsumen mengenai merek yang dapat mempengaruhi perilaku pembelian dan dapat menimbulkan kepercayaan dan kesetiaan terhadap merek (Keller, 2013).

Penyampaian nilai perusahaan melalui komunikasi merek kepada pasar sasaran dan mendapatkan umpan balik yang positif dari khalayak seperti karyawan, pelanggan dan mitra merupakan langkah yang penting untuk dapat memenangkan persaingan (Keller, 2013). Dari semua langkah yang harus diikuti dalam komunikasi merek membangun dan menyampaikan misi, visi, dan tujuan secara benar merupakan hal yang sangat penting dan seharusnya menjadi pertimbangan serius perusahaan dalam pengelolaan komunikasi merek (Ingenhoff \& Fuhrer, 2010).

Visi, Misi, dan tujuan merupakan elemen inti yang tidak berwujud dari sebuah merek dan penyampaian hal ini memegang peranan penting dalam pembentukan citra dan reputasi kompetitif perusahaan secara kuat sehingga dapat membangun hubungan dan keterikatan yang baik dengan konsumen dan hal tersebut tercermin pada isi pesan yang disampaikan oleh merek (Miao, 2021).

Pengelolaan komunikasi merk menjadi sangat penting agar pesan dari merek dapat diterima dengan baik oleh konsumen. Mulai dari menetapkan tujuan komunikasi merk melakukan analisis halayak pemilihan penyampaian pesan pengemasan pesan pemilihan media yang digunakan dalam penyampaian pesan sehingga dapat sesuai dengan halayak sasaran hingga melakukan evaluasi (Risanti et al, 2021).

Pada saat krisis di masa pandemi ini perusahaan biasanya mengurangi pengeluaran pada kegiatan komunikasi atau periklanan. Namun sebenarnya saat ini merupakan waktu terbaik untuk memodifikasi strategi komunikasi agar perusahaan dapat membangun ketahanan merk di kalangan pelanggan (Kotler, 2020). Perusahaan yang tetap menjaga komunikasi dengan pelanggan dapat mengungguli dan memenangkan share of voice yang lebih besar bila kompetitor kurang berkomunikasi atau tidak sama sekali selama periode yang sama (Hoekstra \& Leeflang, 2020). 


\section{Pemasaran Berbasis Empati}

Konsep pemasaran berbasis empati mulai banyak digunakan oleh perusahaan pada kondisi krisis seperti saat ini. Empati sendiri merupakan respon emosional atau afeksi hasil dari pengaruh karakter dan keadaan yang dapat mengaruh pada perilaku dengan penekanan lebih pada bagaimana perasaan penerima bukan pada apa yang kita inginkan (Cameron et al, 2019). Konsep ini digunakan dalam pemasaran untuk menggambarkan bagaimana perusahaan tersebut ikut memikirkan apa yang dirasakan serta dialami oleh konsumennya lebih jauh lagi bagaimana perusahaan tersebut dapat membuat konsumen yang merasa lebih baik. Salah satu alat yang digunakan untuk membuat analisis mengenai empati dalam pemasaran ini adalah menggunakan konsep Empathy Map dari Dave Gray (Coppola, 2017). Kegunaan dari pemasaran berbasis empati ini adalah untuk mengenal target pasar sasaran dengan menyelaraskan antara strategi bisnis serta value proposition dengan kebutuhan keinginan tujuan serta perasaan konsumen.

Konsep pemasaran empati mulai banyak digunakan oleh pemasar dalam memasarkan produknya terutama pada kondisi krisis agar tetap relevan dengan konsumennya. Menurut ilmu psikologi empati adalah pengalaman memahami kondisi orang lain dari sudut pandang orang tersebut menempatkan diri pada posisi orang tersebut dan merasakan apa yang dirasakan (Cuff et al, 2012).

Ketika perusahaan berempati pada konsumen perusahaan tersebut cenderung akan mulai menghasilkan layanan dan produk yang lebih baik sehingga meningkatkan persepsi konsumen mengenai merek dan layanan perusahaan tersebut. Dengan mengimplementasikan empati dalam konsep pemasaran memungkinkan produsen untuk dapat memahami apa yang menjadi kebutuhan pelanggan nomor keluarga dan bahkan. tidak perlu membuat produk yang hanya sekedar menyenangkan untuk di miliki namun memiliki kesempatan untuk menjual produk yang harus dimiliki sehingga memiliki kesempatan unggul lebih besar (Coppola, 2017).

Tujuan dari pemasaran berbasis empati bukan hanya untuk mencari tahu produk apa yang benar-benar dibutuhkan oleh konsumen namun juga untuk dapat selalu relevan dengan konsumen sehingga dapat meningkatkan kepercayaan konsumen pada merek komunikasi mereka tempati yaitu bagaimana merk tersebut berusaha untuk memahami dan bagaimana menempatkan dirinya pada kondisi saat ini isi pesan yang disampaikan oleh mereka tersebut sebisa mungkin relevan dengan situasi yang dihadapi oleh konsumen.

\section{METODE PENELITIAN}

Penelitian ini menggunakan metode penelitian kualitatif deskriptif. Penelitian kualitatif deskripstif menurut Sugiyono yaitu bagaimana mengungkapkan keadaan suatu objek penelitian pada saat penelitian berlangsung sesuai dengan fakta (Sugiyono, 2016). Teknik pengumpulan data yang dilakukan dalam penelitian ini yaitu observasi, dokumentasi dan studi literatur dengan teknik analisis data dalam penelitian. Pengumpulan data tersebut dilakukan secara interaktif yaitu reduksi data penyajian data dan penarikan kesimpulan (Moleong, 2017).

Penelitian ini juga melakukan kajian secara kritis dari pengetahuan ide ataupun temuan pada studi literatur untuk merumuskan kontribusi teoritis dan metodologis untuk tema tertentu. Dalam penelitian ini akan dibahas bagaimana strategi 
komunikasi merek melalui pemasaran berbasis empati yang diterapkan oleh pelaku UMKM di kota Bengkulu selama masa pandemi Covid-19. Adapun yang dikaji adalah isi pesan yang disampaikan dan media yang digunakan oleh pelaku UMKM tersebut dalam menyampaikan pesan dan mempromosikan produknya kepada konsumen.

\section{HASIL DAN PEMBAHASAN}

Pandemi Covid-19 tidak ada yang bisa memastikan kapan berakhir. Maka dari itu para pelaku UMKM harusnya bisa mengatur ulang suatu strategi pemasaran produk-produknya supaya tidak ditinggalkan oleh konsumen. Adapun strategi pemasaran yang akan diterapkan nantinya dimulai dari proses produksi distribusi sampai dengan bagaimana berkomunikasi dengan pelanggan. Untuk saat untuk saat pandemi Covid-19 sekarang ini mau tidak mau transaksi bisnis mengalami perubahan konsumen.

Kondisi krisis memaksa konsumen untuk lebih berhati-hati dalam membelanjakan uangnya dan akan melakukan evaluasi terhadap pembelian produk hanya benar-benar pada yang esensial (Kotler, 2020). Sebagaimana yang kita ketahui merek produk merupakan hal yang sangat penting bagi pasar konsumen. Merek merupakan penghubung antara konsumen dengan perusahaan dan konsumen dapat mengembangkan kebudayaan dan kesetiaan pada merek tersebut (Zehir et al, 2011).

Perubahan perilaku konsumen terjadi di masa pandemi Covid-19 akibat dari penyesuaian terhadap regulasi yang berlaku di masa pandemi, sebagai contoh adanya pembatasan sosial berskala besar yang menyebabkan konsumen lebih banyak melakukan berbagai aktivitas di dalam rumah mulai dari bekerja, sekolah, olahraga sampai dengan berbelanja dan mencari informasi mengenai produk dilakukan melalui pemanfaatan teknologi komunikasi dan informasi. Hadirnya media sosial merepresentasikan adanya perubahan paradigma dalam strategi komunikasi (Jenkins, 2006). Berdasarkan hasil penelitian postingan interaktif lebih banyak mendapat respon dibanding dengan (Kusumasondjadja, 2018). Media sosial Instagram dinilai oleh pelaku UMKM di kota Bengkulu lebih cocok digunakan untuk konten interaktif yang dikombinasikan dengan konten informasi sekaligus menghibur. Istilah lain terkait dengan efektivitas komunikasi pada media sosial juga menemukan bahwa konsumen cenderung mengikuti akun media sosial dari sebuah merek atau produk karena beberapa motif diantaranya untuk memenuhi motif dan simbolik contohnya tetap update mengenai aktivitas promosi untuk mendapatkan informasi mengenai produk baru dan mempunyai kesempatan untuk mempublikasikan dokungan pada merek (Jenkins dalam Risanti et al., 2021).

Tanggapan atau respon dari konsumen merupakan sesuatu yang sangat penting bagi pelaku UMKM karena menandakan jika pesan yang disampaikan dalam media sosial tersebut diterima oleh sasaran. Para pelaku UMKM akan mendapatkan keuntungan pada saat konsumen meneruskan pesan produk pada teman-temannya dan pengikutnya dengan cara membagikan informasi, menandai teman pada kolom komentar agar temannya dapat membaca pesan tersebut. Mengingat postingan yang diteruskan di media sosial dapat dianggap sebagai pesan elektronik dari mulut ke mulut, oleh karena itu menciptakan konten merek pada media sosial bisa memancing respon yang berarti dari konsumen merupakan hal yang sangat penting dalam

@2022 DIKSI (https://jurnal.bimaberilmu.com/index.php/diksi) 
perencanaan strategi pemasaran berbasis empati melalui media sosial dalam hal ini Instagram.

Komunikasi merek melalui pemasaran berbasis empati ini menekankan dua aspek yaitu dari segi isi pesan dan media yang digunakan. Dari segi isi pesan memuat informasi apa saja yang disampaikan oleh penjual untuk menarik konsumen. Pesan tidak hanya terdiri dari informasi mengenai produk makanan atau minuman yang akan dijual atau dipromosikan melalui akun Instagram tetapi juga dalam bentuk gambar atau foto bahkan video. Hanya saja tidak semua pelaku UMKM yang melakukan promosi melalui akun Instagram mereka menyampaikan pesan dalam merek produknya melalui video, tetapi hanya melalui foto dan informasi yang menarik.

Salah satu UMKM yang ada di kota Bengkulu yang menjual produk makanan berupa pempek-pempek ikan dengan merek pempek Bu Alladin. Pada umumnya pempek terbuat dari ikan Tenggiri. Menariknya merek pempek Bu Alladin ini tidak hanya menjual varian pempek yang terbuat dari ikan tenggiri tetapi juga membuat menu pempek dari jenis ikan lainnya seperti ikan Kakap dan ikan Gabus. Di sini bisa kita lihat bentuk inovasi dari pemilik merek pempek Bu Alladin untuk menarik minat konsumen akan membeli produknya dengan tidak hanya menjual pempek yang terbuat dari ikan Tenggiri tapi juga mereka menyediakan pempek yang terbuat dari ikan Kakap ikan Gabus.

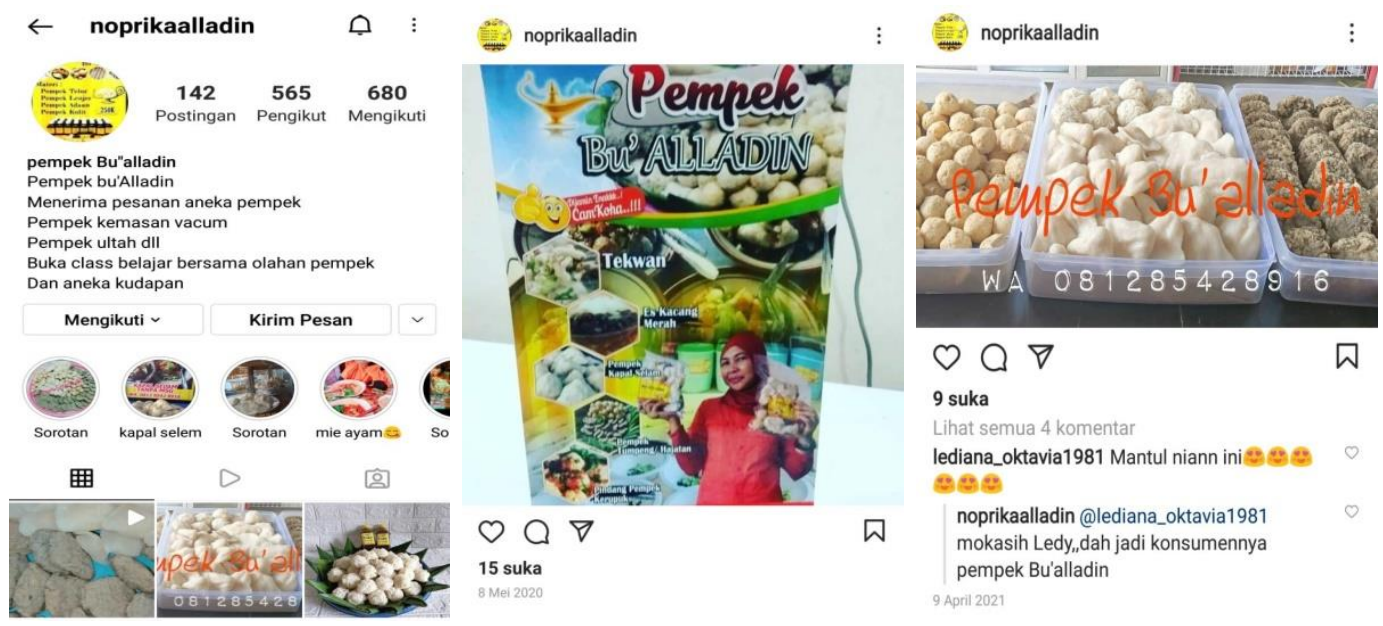

Gambar 1: Akun Instagram Pempek Bu Alladin@noprikaalladin

Upaya ini dilakukan dalam rangka memberikan kepuasan kepada konsumen di Kota Bengkulu untuk mencicipi rasa pempek selain dari ikan Tenggiri dan sebagai bentuk empati dari pelaku UMKM pempek Bu Alladin ini untuk konsumen di Kota Bengkulu yang mayoritas adalah penggemar ikan laut. Dan ikan yang digunakan tidak hanya jenis Tenggiri tetapi juga ada variasi dari jenis ikan laut lainnya seperti ikan Kakap yang ternyata juga bisa di jadikan sebagai bahan utama untuk membuat pempek. Bentuk empati lainnya yang dilakukan oleh pemilik UMKM Bu Alladin adalah menyediakan menu pempek dalam kemasan vakum, sehingga konsumen tidak perlu repot-repot lagi memindahkan pempek jika belum bisa langsung memakannya sehingga bisa langsung disimpan di dalam lemari pendingin.

Penggunaan media sosial Instagram sebagai media komunikasi yang digunakan oleh merek pempek Bu Alladin ini bisa menyampaikan pesan mereknya 
secara efektif dan bisa mempertahankan hubungan baik dengan konsumen. Hal ini bisa dilihat dari banyaknya konsumen yang menjadi follower akun Instagramnya.

Usaha pempek Bu Alladin ini juga mendukung program pemerintah dalam menghambat laju persebaran virus Covid-19 di Kota Bengkulu dengan memilih berjualan secara online yaitu dengan cara memesan melalui nomor aplikasi chat seperti WhatsApp, sehingga pembeli tidak harus keluar rumah untuk bisa menikmatinya. Hal tersebut juga merupakan bentuk implementasi dari strategi komunikasi merek berbasis empati dimana merek mencoba memahami apa yang menjadi perhatian utama pembeli dalam hal ini kekhawatiran terhadap penularan virus sehingga pemberian dukungan pada upaya pencegahan penularan dengan transaksi online merupakan cara yang tepat untuk dilakukan pada kondisi pandemi Covid-19 sampai saat ini.

Strategi komunikasi merek melalui pemasaran empati ini juga bisa dilihat pada UMKM dengan merek Cavin Kuliner. UMKM dengan merek Cavin Kuliner ini menyuguhkan produk berupa makanan ala Korea. Varian makanan ala Korea di Kota Bengkulu sebenarnya tidak hanya bisa didapat melalui UMKM kuliner ini karena di Kota Bengkulu juga ada beberapa restoran yang mengusung rumah makan dengan variasi menu makanan yang sama. Meskipun varian menu yang sama-sama mengusung makanan ala Korea namun Cavin Kuliner ini lebih banyak menyediakan variasi menu berupa cemilan ala Korea. Hal ini bisa dilihat dari banyaknya menu camilan ala Korea dengan bahan makanan ciri khas dari negeri ginseng tersebut, seperti menu Toppokki, Tteokbokki dan Rappoki. Sementara media yang digunakan oleh UMKM Cavin Kuliner ini juga melalui Instagram.

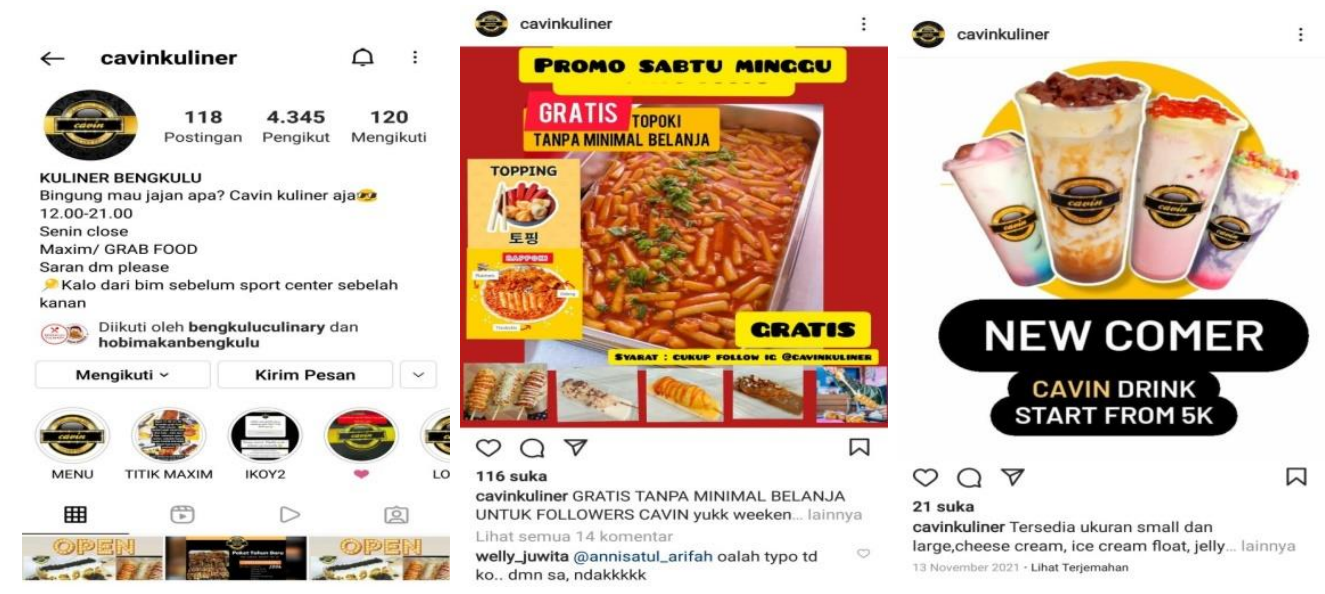

Gambar 2: Akun Instagram Cavin Kuliner@cavinkuliner

Dilihat dari akun Instagramnya UMKM ini banyak menyediakan promo-promo untuk para pembeli dan promo-promo ini sifatnya itu temporal atau menyesuaikan dengan momen tertentu. Banyak masyarakat di Kota Bengkulu yang menyukai variasi menu makanan ala korea ini disebabkan karena sebagian besar masyarakat menggandrungi drama Korea, sehingga hal tersebut dijadikan sebagai peluang untuk menciptakan inovasi baru dalam dunia kuliner di Kota Bengkulu. Meskipun menu yang diusung adalah ciri khas dari Korea tetapi dari segi rasa tidak ada perbedaan yang terlalu berarti dan dari segi harga pun juga sangat terjangkau. Hal ini dilakukan melihat kondisi pandemi Covid-19 yang masih belum memungkinkan masyarakat di Kota Bengkulu itu sendiri bisa mendapatkan penghasilan secara rutin sehingga para

@2022 DIKSI (https://jurnal.bimaberilmu.com/index.php/diksi) 
pelaku UMKM di kota Bengkulu termasuk Cavin Kuliner ini menyesuaikan dengan kondisi pendapatan masyarakat di Kota Bengkulu.

Adapun komunikasi merek yang dilakukan oleh Cavin Kuliner melalui akun Instagramnya berupa promo yang diberikan setiap weekend dan informasi mengenai menu baru yang mereka racik, seperti yang kita lihat menu baru berupa minuman kekinian yang sangat digandrungi oleh sebagian besar konsumen muda di Kota Bengkulu. Minuman kekinian tersebut hanya dibanderol dengan harga yang sangat terjangkau karena mengingat pasar dari minuman kekinian tersebut adalah kalangan muda di Kota Bengkulu. Bentuk komunikasi merek lainnya yang dilakukan oleh Calvin Kuliner ini berupa pemberian promo yaitu dengan membeli makanan di Cavin Kuliner maka akan diberikan gratis makanan tambahan tanpa ada minimal pembelian. Strategi komunikasi merek tersebut sangat menarik karena menyesuaikan dengan situasi dan kondisi perekonomian masyarakat yang bisa dikatakan masih berada di level kelas menengah ke bawah.

Apa yang dilakukan oleh Cavin Kuliner tersebut juga merupakan bagian dari strategi pemasaran UMKM itu sendiri dalam bentuk adaptasi. Adaptasi merupakan strategi pemasaran yang paling penting sebagai antisipasi adanya perubahan dunia usaha terutama UMKM pada masa normal. Adanya anjuran untuk mematuhi protokol kesehatan selama pandemi Covid-19 dijadikan sebagai bahan evaluasi bagi pelaku UMKM di kota Bengkulu untuk melakukan penyesuaian dengan merek produk yang akan mereka jual kepada konsumen. Bentuk adaptasi yang dilakukan para pelaku UMKM di kota Bengkulu itu adalah melakukan penjualan secara penjualan secara online melalui aplikasi layanan transportasi online seperti Grab melalui fitur grab food, sehingga pembeli tidak harus keluar rumah untuk membeli, cukup dengan memesan melalui aplikasi mereka sudah bisa menikmati sambil mematuhi protokol kesehatan dari pemerintah yaitu tetap berada di rumah.

Strategi komunikasi merek berbasis empati ini juga bisa dilihat dari penentuan harga produk yang ditawarkan oleh pelaku UMKM. Situasi pandemi yang menyebabkan berkurangnya pemasukan masyarakat membuat pelaku UMKM di kota Bengkulu membuat strategi komunikasi merek berbasis empati melalui penetapan harga produk yang sangat terjangkau. Penentuan harga produk di sini berkaitan dengan kualitas dari produk itu sendiri dengan kata lain konsumen bisa menolak produk dengan label harga yang lebih tinggi atau bahkan lebih rendah jika cita rasanya tidak sesuai.

Media sosial Instagram yang dijadikan sebagai wadah berjualan bisa menekan biaya produksi dan biaya promosi karena menggunakan media sosial di Instagram tidak semahal iklan di media konvensional seperti televisi dan radio. Imbasnya adalah bagi pelaku UMKM bisa merasakan keuntungan yang maksimal dengan kualitas produk yang tetap terjaga tanpa harus memikirkan apakah akan menaikkan harga lagi. 




Gambar 3: Akun Instagram Dimsum Nona @dimsum_nonal6

Harga yang cukup kompetitif tersebut bisa dilihat dari komunikasi merek berbasis empati yang dilakukan oleh pelaku usaha UMKM dari Dimsum Nona dan Geboy Street Food \& Drink. Kedua pelaku UMKM tersebut menetapkan harga yang sangat ekonomis dan terjangkau dengan variasi menu makanan yang beragam dan variasi menu minuman kekinian yang beragam pula. Tampilan pesan yang menarik dalam promo akun Instagram mereka membuat pembeli tertarik untuk mencicipi varian menu andalan yang mereka buat. Mereka cukup menuliskan kata promo berkah dengan harga sangat ekonomis untuk tiga varian menu makanan dan beli 1 cup minuman kekinian gratis cemilan dengan harga yang sangat terjangkau, sebagai strategi untuk menarik minat konsumen. Harga yang terjangkau tersebut bisa menggugah minat pembeli sekaligus sebagai bentuk empati untuk masyarakat yang ingin menikmati sajian kuliner yang lain dari yang lain dengan menyesuaikan budget yang mereka miliki, sehingga ada hubungan antara pembeli dengan penjual karena pembeli akan mengingat jika pelaku kedua pelaku UMKM tersebut seringkali melakukan promo terhadap produknya.

Keunggulan dari pemasaran melalui media sosial adalah kecepatan informasi yang bisa diterima oleh audiens. Semakin cepat informasi menyebar semakin banyak audiens yang akan melihat. Dalam Instagram, informasi bisa menyebar sangat cepat jika didukung dengan postingan yang menarik. Hal ini bisa mempengaruhi audiens untuk mengunjungi dan kemudian menjaki pengikutnya.

Strategi ini juga diikuti oleh pelaku UMKM dengan merek minuman kekinian Minumin Bengkulu. Konsumen bisa mengunjungi dan mengikuti akun Instagramnya di@minumin.bkl. Produk minuman kekinian saat ini sangat digandrungi terutama oleh kaum muda di Kota Bengkulu. Memanfaatkan kondisi geografis Kota Bengkulu terletak di daerah pesisir dengan udara yang panas, menjadikan Minumin Bengkulu mendapat sambutan yang sangat baik. Kaum muda di Kota Bengkulu bisa menikmati segarnya minuman dingin disaat udara terik dengan berbagai macam varian rasa. 

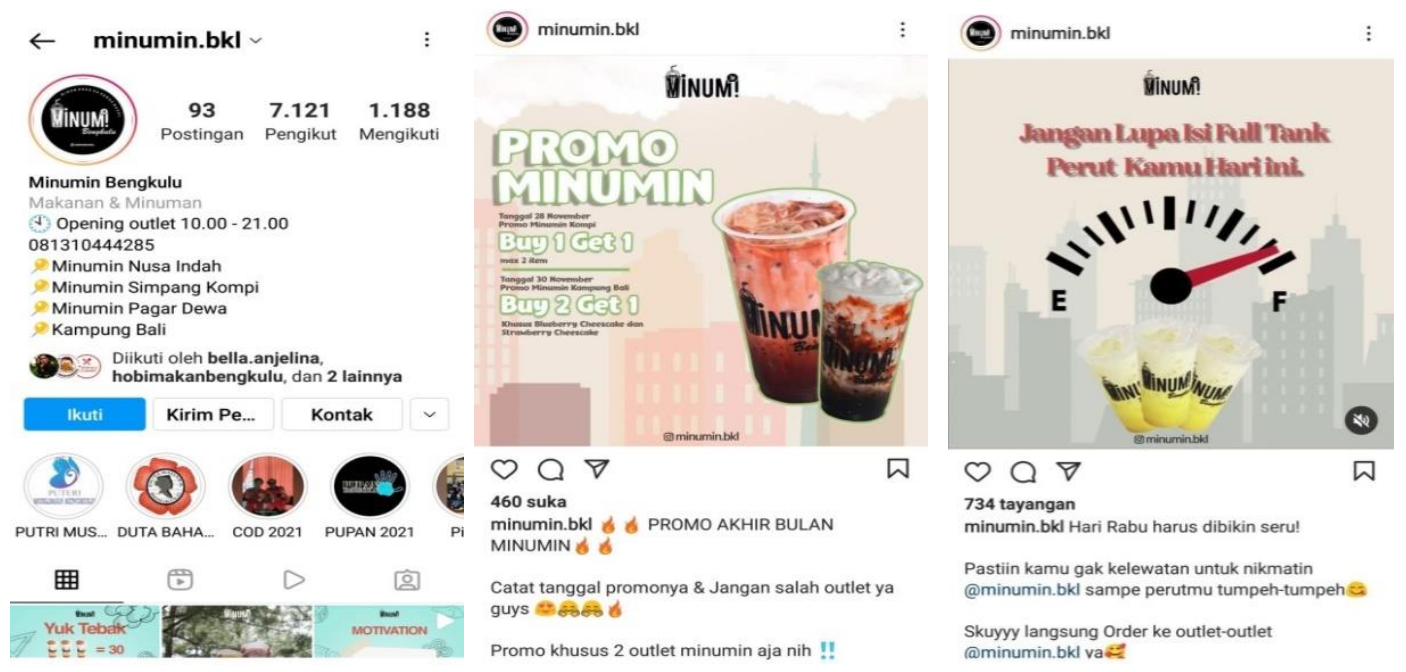

Gambar 4: Akun Instagram Minumin Bengkulu @minumin.bkl

Merek bisa mengkomunikasikan kebutuhan konsumen melalui pesan dalam pemasaran berbasis empati. Pesan dalam merek ini mampu mempengaruhi psokologis konsumen untuk selalu mengingatnya. Strategi ini juga dilakukan oleh pelaku UMKM Minumin Bengkulu melalui akun Instagramnya. Sentuhan perhatian menjadi fokus utama dalam pesan merek yang dikomunikasin kepada calon konsumen. Bisa dilihat dari postingan akunnya, Minumin Bengkulu mencantumkan kata "Jangan Lupa Isi Full Tank Perut Kamu Hari Ini” yang menggugah calon konsumen untuk selalu mengingat produk minuman kekinian ini, sekaligus mengingatkan untuk jangan membiarkan perut lapar terlalu lama karena akan berpengaruh terhadap kesehatan di masa pandemi ini.

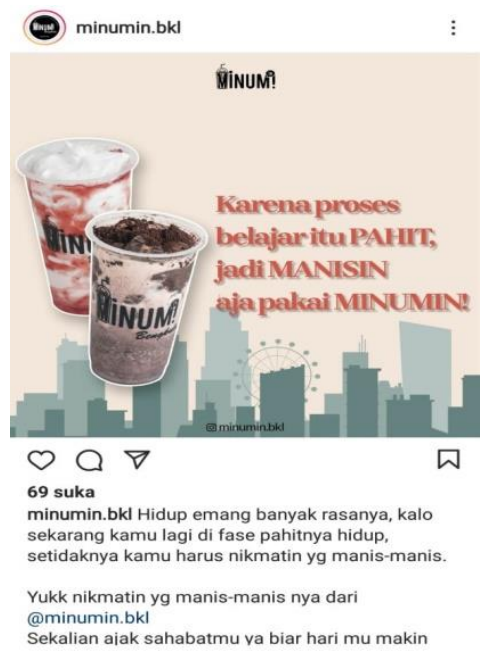

Gambar 5: Akun Instagram Minumin Bengkulu @minumin.bkl

Postingan berikutnya juga sarat akan pesan komunikasi merek berbasis empati dengan mencantumkan kata "Karena Proses Belajar Itu Pahit, Jadi Manisin Aja Pakai Minumin!". Pesan tersebut tentu saja memuat informasi berupa wejangan mengenai proses belajar yang tidak selalu berjalan mulus, sehingga perlu sabar menjalaninya. Mengingat calon konsumennya adalah kaum muda, pesan komunikasi merek tersebut mampu membangkitkan jiwa semangat mereka tanpa terkesan menggurui. Di masa pandemi sekarang ini tingkat kesabaran sangat diperlukan, 
terutama dalam taat menjalankan protokol kesehatan. Dengan demikian, protokol kesehatan tetap diterapkan tetapi kebutuhan berbelanja kekinian tetap terpenuhi.

Berdasarkan pemaparan di atas, bisa dikatakan bahwa strategi komunikasi merek melalui pemasaran berbasis empati terdiri dari dari beberapa tahapan melalui isi pesan dan media yang digunakan. Pemasaran empati melalui komunikasi yang dilakukan oleh merek pelaku UMKM di Kota Bengkulu berfokus pada kebutuhan dan kemampuan konsumen selama pandemi Covid-19 disaat harus mematuhi protokol kesehatan. Anjuran untuk jaga jarak dan di rumah saja membuat pelaku UMKM melakukan berbagai inovasi dan adaptasi untuk menciptakan produk yang menarik konsumen. Selain itu, kondisi pandemi yang berlangsung mengakibatkan menurunnya pendapatan baik pelaku UMKM ataupun konsumen, membuat mereka berinisiatif menawarkan harga yang terjangkau sesuai dengan kualitas produk. Sehingga, konsumen tetap setiap membeli produk mereka dan disaat bersamaan pelaku UMKM tidak mengalami kerugian. Hal ini bisa dilihat isi pesan merek berupa pemberian promo harga terutama untuk varian makanan atau minuman baru tanpa mengubah kualitas dan cita rasanya, menambahkan kata wejangan atau perhatian yang menggugah emosi konsumen untuk mengingatnya.

Media sosial yang banyak digunakan oleh pelaku UMKM di Kota Bengkulu adalah Instagram. Penggunaan Instagram ini dengan memanfaatkan semua fitur, mulai dari insta story, postingan, foto dan video. Pemanfaatan semua fitur tersebut dalam rangka merek menjaga hubungan baik dengan konsumen melalui pesan merek yang interaktif dan menarik sehingga pengikutnya atau calon pembeli bisa menerima kehadiran merek. Pesan merek disampaikan melalui akun Instagram resmi pelaku UMKM, sehingga pembeli bisa melihat kredibilitasnya.

Di masa pandemi ini tentunya pendapatan pelaku UMKM mengalami penurunan, tetapi masih bisa memberikan yang terbaik bukan saja kepada konsumennya tetapi juga kepada khalayak luas. Bagian yang paling penting dalam strategi komunikasi merek melalui pemasaran berbasis empati ini adalah bisa membangun emosional yang kuat sebagai upaya menjangkau konsumen sekaligus membuat mereka merasa terhubung melalui promosi yang dilakukan. Merek sebuah produk yang memiliki ikatan emosional yang kuat dengan konsumen merupakan bentuk komunikasi merek melalui pemasaran yang berbasis empati.

\section{KESIMPULAN}

Strategi komunikasi merek melalui pemasaran berbasis empati ini sangat penting diterapkan oleh pelaku UMKM di Kota Bengkulu. Dalam menjalankan strategi komunikasi merek ini dilakukan melalui dua segi yaitu dari segi isi pesan dan media yang digunakan. Dari segi isi pesan, pada masa pandemi Covid-19 konsumen menjadi sangat sensitif dan tanggap terhadap komunikasi merek. Konsumen cenderung melihat dengan seksama bagaimana merek yang tetap menjaga relevansi dengan kondisi yang terjadi dan menjadi pertimbangan utama dalam memilih atau membeli produk dari merek produk yang dijual oleh pelaku UMKM di Kota Bengkulu.

Pesan yang disampaikan dalam mengkomunikasikan merek produk yang dijual oleh pelaku UMKM di kota Bengkulu melalui pemasaran berbasis empati ini berfokus pada pemilihan kata-kata yang menarik dan menyentuh emosi dari pembeli.

@ 2022 DIKSI (https://jurnal.bimaberilmu.com/index.php/diksi) 
Selain itu juga beberapa UMKM sengaja menggunakan kalimat yang bersifat menghibur dan memberi perhatian kepada konsumen.

Dari segi media yang digunakan sebagian besar pelaku UMKM di kota Bengkulu menggunakan media sosial sebagai wadah untuk mereka berjualan. Media sosial dipilih adalah Instagram karena media ini menyediakan fasilitas atau fitur yang bisa dimanfaatkan oleh pelaku UMKM di Kota Bengkulu melakukan promosi berupa foto atau gambar dan video. Selain itu juga pemilihan Instagram sebagai media untuk berjualan karena bisa meningkatkan kreativitas produk yang dijual, mampu mengoptimalkan media yang ada untuk menambah jaringan relasi pemasaran sehingga mempermudah melakukan promosi produk.

Rekomendasi secara praktis yang bisa diberikan kepada pelaku UMKM di Kota Bengkulu khususnya untuk meningkatkan penjualan selama pandemi Covid-19 berupa kemampuan atau skill dalam mengemas pesan komunikasi merek melalui pemasaran berbasis empati. Inovasi atau kebaruan informasi sebaiknya perlu ditinggkatkan kembali guna menarik perhatian sekaligus mengingat emosi konsumen, sehingga merek produk yang dijual akan terus diingat dan konsumen merasa terus terhubung. Selain itu, mengingat kondisi pandemi Covid-19 yang belum membaik sebaiknya ikut mendukung pemerintah dalam menegakkan protokol kesehatan tidak hanya dari segi mendukung masyarakat untuk tidak keluar rumah melalui pembelian online, tetapi juga disetiap pesan komunikasi merek yang dibuat saat promosi selalu mengingatkan masyarakat bahwa pandemi Covid-19 belum berakhir.

\section{DAFTAR PUSTAKA}

Aaker, A. D. (2012). Building Strong Brands. New York: The Free Press.

Aaker, A. D. (2014). Aaker on Branding: 20 Principles That Drive Success. New York: Morgan James Publishing.

Cameron, C. D., Hutcherson, C. A., Ferguson, A. M., Scheffer, J. A., Hadjiandreou, E., \& Inzlicht, M. (2019). Empathy Is Hard Work: People Choose to Avoid Empathy Because of Its Cognitive Costs. Journal of Experimental Psychology: General, Online Fir(1), 1-15. Retrieved from http://dx.doi.org/10.1037/xge0000595.

Coppola, G. (2017). What is an Empathy Map, and why is it valuable for your business? Retrieved from medium.com website: https://medium.com/swlh/whatis-an-empathy-map-and-why-is-it-valuable-for-your-business-14236be4fdf4.

Cuff, B., Brown, S. J., Taylor, L., \& Howat, D. (2012). Empathy: A review of the concept. Emotion Review, Publish On. Retrieved from http://emr.sagepub.com/content/early/2014/12/01/1754073914558466.

Hoekstra, J. C. \& Leeflang, P. S. H. (2020). Marketing in the Era of Covid-19. Italian Journal of Marketing, 20(1), 249-260. Retrieved from https://doi.org/10.1007/s43039-020-00016-3\%0A.

Ingenhoff, D. \& Fuhrer, T. (2010). Positioning and Differentiation by Using Brand Personality Attributes. Corporate Communications: An International Journal, 15(1), 83-101. 
Jenkins, H. (2006). Fans, Bloggers, and Gamers: Exploring Participatory Culture. New York: New York University Press.: New York University Press.

Keller, K. L. (2013). Strategic Brand Management (Global Edi). London: Pearson Education International.

Kotler, P. (2020). The Consumer in the Age of Coronavirus. Retrieved from The Marketing Journal website: https://www.marketingjournal.org/the-consumer-inthe-age-of-coronavirus-philip-kotler/.

Kotler, P. \&, \& Keller. (2012). A Framework for Marketing Management (Internatio). Edinburgh: Pearson Education International.

Kusumasondjadja, S. (2018). The Roles of Message Appeals and Orientation on Social Media Brand Communication Effectiveness: An Evidence from Indonesia. Asia Pacific Journal of Marketing and Logistics, 30(4), 1135-1158.

Miao, Y. (2021). Brand Communication of Intangible Elements Delivery. Journal of Marketing Communications, 7(3). Retrieved from https://doi.org/10.1080/13527266.2019.1674363

Moleong, L. J. (2017). Metode Penelitian Kualitatif. Bandung: Remaja Rosdakarya.

Risanti, Yuliani., Dewi., Anisa., Renata., dan Prihandini., Puji. (2021). Pemasaran Empatik Sebagai Strategi Komunikasi Merek Di Masa Pandemi Covid-19. Jurnal Manajemen Komunikasi, Vol.5, No.2, Maret 2021, hlm.218-237.

Steimer, S. (2020). How Marketers Are Working During the Pandemic. Retrieved from American Marketing Association website: https://www.ama.org/marketingnews/how-marketers-are-working-during-the-pandemic/

Sugiyono. (2016). Metode Penlitian, Kuntitatif, Kualitatif, dan R\&D. Bandung: Alfabeta.

Zehir, Cemal., Azize Şahin., Hakan Kitapçı., Mehtap Özşahin. (2011). The Effects of Brand Communication and Service Quality In Building Brand Loyalty Through Brand Trust; The Empirical Research On Global Brands. Procedia - Social and Behavioral Sciences, 24, 1877-0428. Retrieved from https://doi.org/10.1016/j.sbspro.2011.09.142. 